\title{
Application of a basic monitoring strategy for Cryptosporidium and Giardia in drinking water
}

\author{
MV Sigudu' ${ }^{1 *}, \mathrm{HH}$ du Preez ${ }^{1,2}$ and F Retief ${ }^{3}$ \\ 'Rand Water, Scientific Services, PO Box 3526, Vereeniging, 1930, South Africa \\ 2University of Johannesburg, Department of Zoology, PO Box 524, Auckland Park, 2006, South Africa \\ ${ }^{3}$ North West University, School of Geography and Environmental Management, Private Bag X6001, Potchefstroom, 2520, South Africa
}

\begin{abstract}
Despite the health risks associated with exposure to Cryptosporidium and Giardia, there is no uniform approach to monitoring these protozoan parasites across the world. In the present study, a strategy for monitoring Cryptosporidium and Giardia in drinking water was developed in an effort to ensure that the risk of exposure to these organisms and the risks of non-compliance to guidelines are reduced. The methodology developed will be applicable to all water supply systems irrespective of size and complexity of the purification works. It is based on monitoring procedures proposed by the US Environmental Protection Agency, the Drinking Water Inspectorate, Australia and New Zealand, as well as the risk-based procedure followed by Northern Ireland. The monitoring strategy developed represents a preventative approach for proactively monitoring Cryptosporidium and Giardia species in drinking water. The strategy consists of 10 steps: (i) assessment of the monitoring requirements, (ii) description and characterisation of the source water types, (iii) abstraction of source water, (iv) assessment of the water purification plant, (v) water quality monitoring, (vi) cryptosporidiosis and giardiasis outbreak, (vii) risk assessment, (viii) sample collection and laboratory processing, (ix) data evaluation, interpretation and storage, (x) process evaluation and review. Proper implementation of this protocol can contribute to the protection of drinking water consumers by identifying high-risk source water, identifying areas of improvement within the water treatment system, and also preventing further faecal pollution in the catchments. The protocol can also be integrated into the Water Safety Plans to optimise compliance. Furthermore, this methodology has a potential to contribute to Blue Drop certification as it should form part of the incident management protocols which are a requirement of Water Safety Plan implementation.
\end{abstract}

Keywords: Cryptosporidium, Giardia, monitoring, risk score, drinking water

\section{INTRODUCTION}

Cryptosporidium and Giardia are intracellular protozoan parasites that infect the gastrointestinal tract of vertebrate animals including mammals, birds, reptiles, and fish (Carmena, 2010). They enter surface waters such as lakes, ponds and dams as environmentally resistant cysts and oocysts in the faeces of infected people or animals. Cryptosporidium and Giardia can cause human cryptosporidiosis and giardiasis, respectively, which are the most common causes of protozoal diarrhoea worldwide (Cacciò et al., 2005). The transmission of Cryptosporidium and Giardia occurs mainly through the faecal-oral route by direct contact with contaminated faeces and by exposure to contaminated food and water (Carmena et al., 2012). The water exposure routes include ingestion of water during recreational activities (swimming, canoeing, and skiing), and drinking untreated and treated tap water contaminated with Cryptosporidium and Giardia oocysts.

Monitoring of Cryptosporidium and Giardia is done throughout the world and the data obtained have been used for conducting risk assessment, for evaluation of water treatment system reliability and also to assist with waterborne outbreak investigations (Bentacourt and Rose, 2004). However,

\footnotetext{
To whom all correspondence should be addressed.

뚕 +27 16430 8423; Fax: +27 16430 8460;

e-mail: ksigudu@randwater.co.za

Received 11 April 2013; accepted in revised form 27 February 2014.
}

different approaches for Cryptosporidium and Giardia monitoring are used in different countries (US EPA, 2006; DWI, 2008; NZ Ministry of Health, 2008; NI Department for Regional Development, 2007). In the USA the log-reduction method is used (US EPA, 2006), while risk-based approaches are commonly applied in the United Kingdom and New Zealand (DWI, 2008; NZ Ministry of Health, 2008). In South Africa, Cryptosporidium and Giardia monitoring in drinking water supply systems is not pervasive. In the few systems where it is performed, the focus is mainly on the final treated water.

From the preceding, it is evident that there is no uniform strategy for monitoring these protozoan parasites in drinking water supply systems. Hence the overall objective of the study was to develop and apply a methodology that can be used by drinking water utilities to monitor Cryptosporidium and Giardia. The test site used was a small potable water treatment plant using surface water abstracted from the Vaal River Barrage, Gauteng Province as source water. It must be stressed that this methodology is based on monitoring procedures proposed by the US Environmental Protection Agency (USEPA) (2006), the Drinking Water Inspectorate (DWI, 2008), Australian Drinking Water Quality Guidelines (NHMRC, 2004), Drinking Water Standards New Zealand (NZ Ministry of Health, 2008), and especially on the riskbased procedure followed by Water Supply Water Quality Regulations Northern Ireland (NI Department for Regional Development, 2007). 


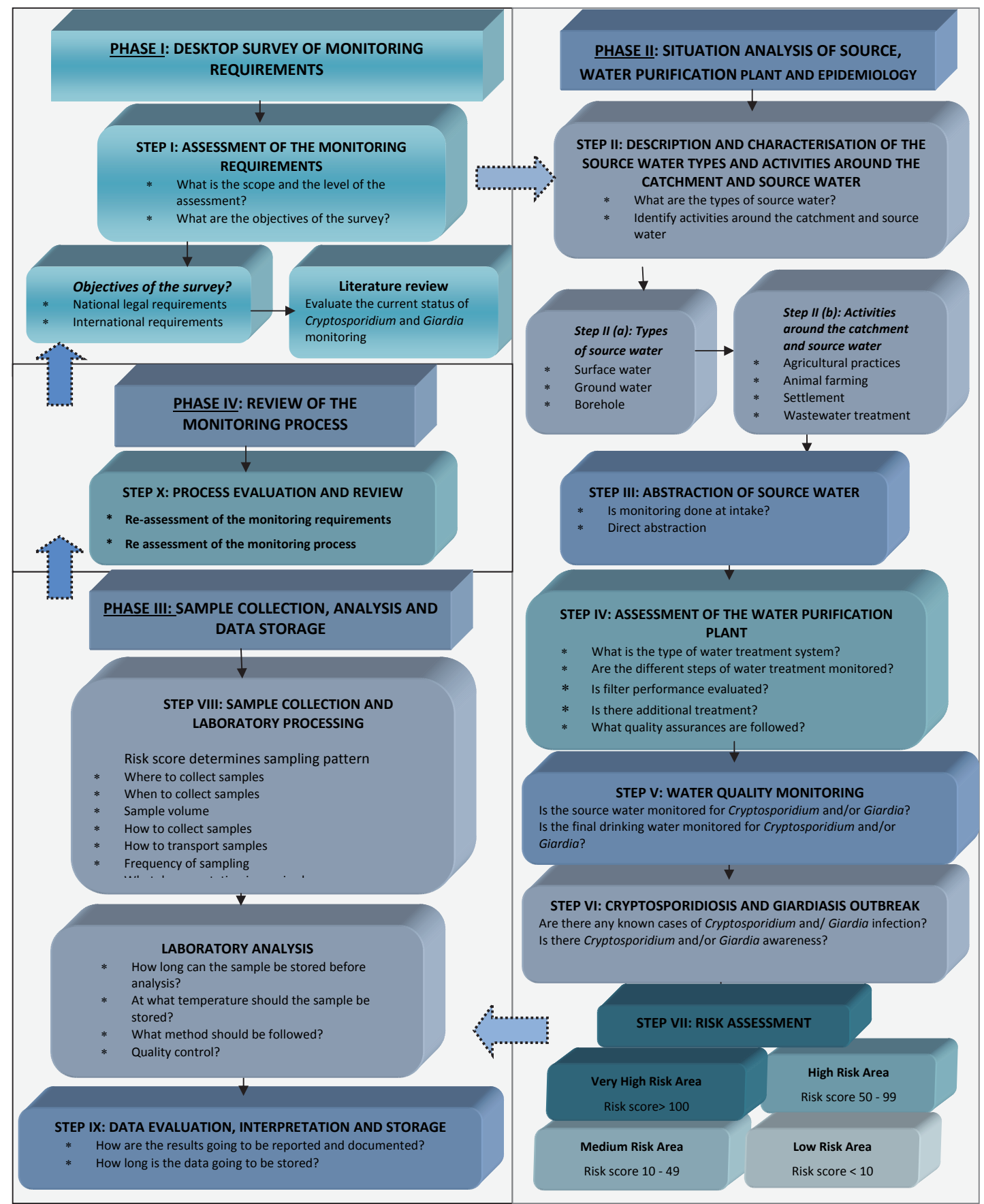

Figure 1

The protocol for management of Cryptosporidium and Giardia in drinking water

\section{EXPERIMENTAL}

\section{Elements of the protocol}

This protocol involves desktop studies, surveys, as well as laboratory analysis with scores assigned during the surveys. It includes 10 major steps that should be followed sequentially for monitoring of Cryptosporidium and Giardia by water utilities (Fig. 1).

These steps are grouped into 4 major phases, namely:

- PHASE I: Desktop survey of monitoring requirements

- PHASE II: Situation analysis of source, water purification plant and epidemiology
- PHASE III: Sample collection, analysis and data storage

- PHASE IV: Review of the monitoring process

At the end of each assessment the total score can be determined. These are then used to calculate the risk of Cryptosporidium/Giardia contamination.

\section{Detailed description of the phases and steps of the protocol}

\section{PHASE I: Desktop survey of monitoring requirements}

This phase involves the accessing of current information on 


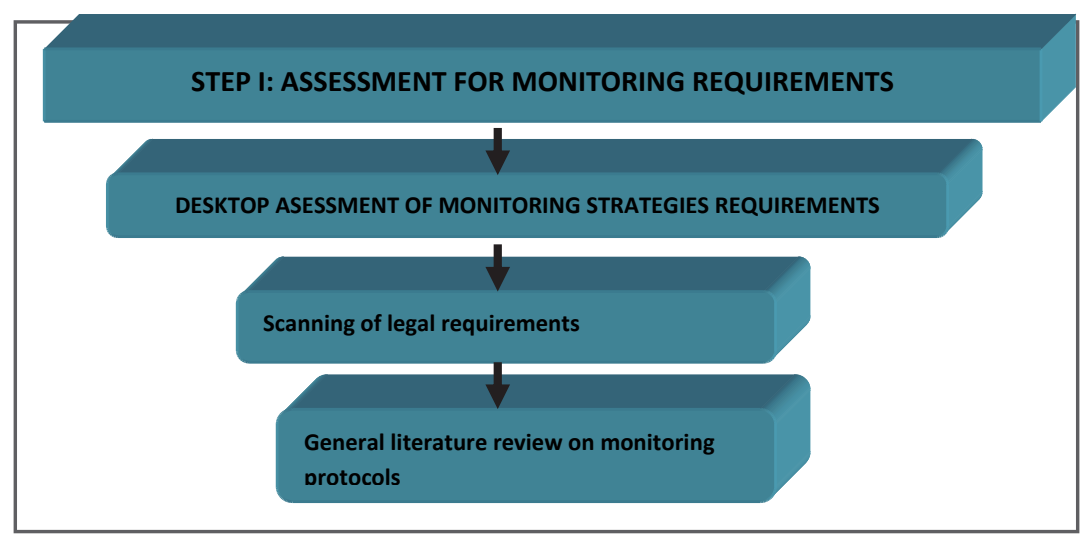

Figure 2

The activities involved during assessment of the monitoring requirements
Cryptosporidium and Giardia from published and non-published sources and forms part of the first step of the protocol. However, if improvements in technology have been made or when there are changes in the national standards and acts, it is advisable that the water utility revisit the sites to update the protocol.

\section{Step I: Assessment for monitoring requirements (Fig. 2)}

This is a desktop study for evaluating monitoring strategies required for Cryptosporidium and Giardia. During this step, the national water related legislation (Acts and standards) must be scanned in order to understand the legal requirements for Cryptosporidium and Giardia in drinking water and source water. This will give an insight into current minimum requirements for monitoring Cryptosporidium and Giardia in water bodies used for domestic purposes, and agricultural as well as recreational purposes. In South Africa, national acts and standards apply, such as the South African National Standard (SANS) 241 (2011) for drinking water, National Water Act (NWA) (No. 36 of 1998) (RSA, 1998), and Water Services Act (WSA) (No. 108 of 1997) (RSA, 1997).

The international legal requirements should also be reviewed to gain further insight into the current global practices regarding Cryptosporidium and Giardia monitoring. The international standards and acts to be scanned include those of the U.S. Environmental Protection Agency (US EPA, 2006), Drinking Water Standards New Zealand (NZ Department of Health, 2008), Australian Drinking Water Quality Guidelines (NHMRC, 2004), the Drinking Water Inspectorate (DWI, 2008), the Water Supply (Water Quality) Regulations Northern Ireland (NI Department for Regional Development, 2007), and other relevant international acts and standards applicable during the assessment.

\section{Application}

The site used to test the protocol was the Vaal River Barrage Drinking Water Production Plant which uses the water from the Vaal River Barrage Reservoir as source water. The Vaal River Barrage Reservoir is situated on the lower Vaal River in Gauteng (South Africa) and covers an area of approximately 64 $\mathrm{km}^{2}$ with an estimated storage capacity of $63 \times 10^{6} \ell$ (RW, 2008).

Two main approaches for monitoring protozoan parasites have been identified. These are the log-reduction approach, applied in the United States (USEPA, 2006) and New Zealand (NZ Department of Health, 2008), and the risk-based assessment followed in the United Kingdom (DWI, 2008) and
Northern Ireland (NI EHS, 2002). In Cryptosporidium and Giardia monitoring in other countries such as Canada there are no minimum acceptable concentrations for these protozoans (Health Canada, 2008).

In South Africa drinking water quality is evaluated against the South African National Standard (SANS) 241-1. According to SANS 241-1 (2011) the operational water quality values for Cryptosporidium and Giardia in drinking water are less than 1 oocyst $/ 10 \ell$ and 1 cyst $/ 10 \ell$, respectively. The standard further stipulates that the final water be monitored monthly for Cryptosporidium and Giardia. Yet, not all water utilities in South Africa monitor for these parasitic protozoans as there is no standard protocol for their monitoring. The drinking water produced by the Vaal River Barrage Drinking Water Production Plant must therefore comply with SANS 241-1 (2011), and Rand Water monitors the levels of Cryptosporidium and Giardia in the final and source water of the plant every second week.

\section{Phase II: Situation analysis of source, water purification plant and disease outbreak}

This phase involves conducting an on-site assessment of the source water, facilities, equipment, operation and maintenance of the entire drinking water system. This is an intensive phase of the survey which includes Steps II - VII of the protocol. During this survey the source water and the water treatment plant can be evaluated for the risk of Cryptosporidium and Giardia contamination. At the end of this phase the risk of the complete water treatment system can be categorised into either 'very high risk', 'high risk', 'medium risk' or 'low risk'.

\section{Step II (a): Description and characterisation of the source water types (Fig. 3)}

The source water is characterised in order to identify the possibility of Cryptosporidium and Giardia contamination. Source water types could be classified into:

- Protected groundwater - groundwater is usually protected against contamination from the surface by soils and covering rock layers (ESSF, 2005). In other cases groundwater may be protected by defining source protection zones within which development is limited in order to reduce the chance of spillage of potentially polluting substances

- Unprotected groundwater - is not protected from possible impact from human sewage or livestock faecal material (NZ Department of Health, 2008).

- Protected surface water catchments - as with groundwater, 


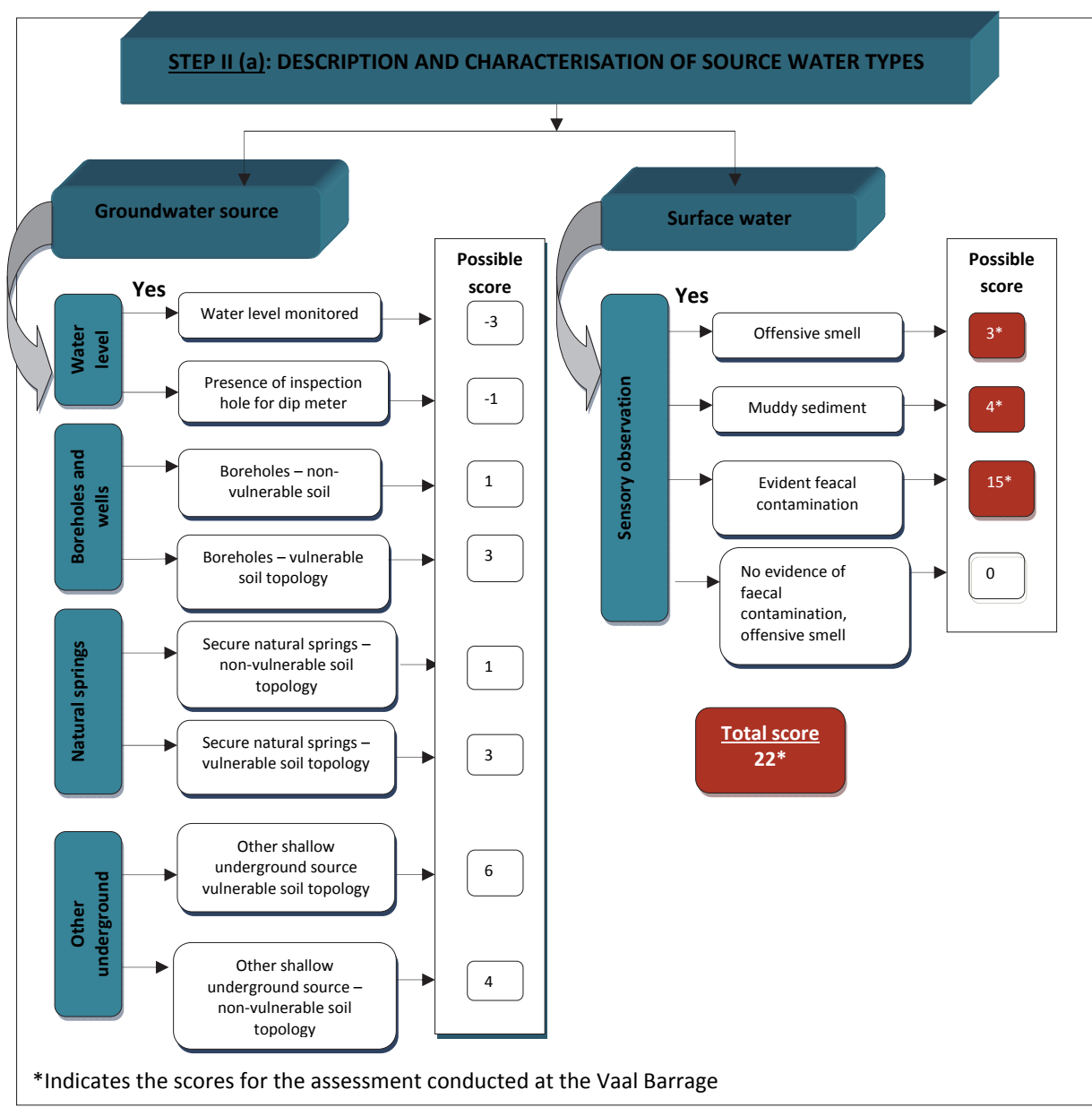

Figure 3

Description of various activities to assess for when characterising the source water (adapted from NI EHS, 2002) surface water could be protected by defining source protection zones within which development is limited in order to reduce the chance of spillage of potentially polluting substances.

- Protected surface water usually contains low to moderate numbers of $E$. coli and should be considered as being vulnerable to contamination by enteric viruses, protozoa and bacteria (NZ Department of Health, 2008).

- Unprotected surface water - lacks defined protection zones and can be subject to contamination by enteric viruses, protozoa and bacteria (NZ Department of Health, 2008).

- Reclaimed water - reclaimed water for potable use is not protected from faecal contamination.

The monitoring requirements for water supplies derived from protected groundwater are different from those for water supplies derived from unprotected surface water. Protected surface water catchments should contain low-moderate numbers of E. coli, whereas unprotected surface water can be subject to contamination by enteric viruses, protozoa and bacteria (US EPA, 2006). Any observations of the source water that could indicate the possibility of faecal contamination become of importance as it may assist in risk classification given that human sewage and livestock faecal material are the predominant source of human-infective Cryptosporidium and Giardia (NZ Department of Health, 2008).

\section{Application}

At the Vaal River Barrage plant, unprotected surface water is used as source water. Visual assessment at the Vaal River Barrage Drinking Water Production Plant abstraction point indicated that there was no evidence of faecal pollution or offensive odours. The bottom sediment was muddy and the abstraction is done at the reservoir wall (Fig. 3).

Step II (b): Assessment of the activities around the catchment and the source water (Fig. 4)

The activities around the catchment and source water should be assessed in order to determine the processes that drive and determine the characteristics of the water quality in that specific source water and the catchment (Du Preez et al., 2003). The quality of drinking water sources is threatened by land development, runoff from agricultural, commercial and industrial sites, farmed animals, ageing wastewater infrastructure, and urbanisation, as well as the type of settlement around the source (Murray et al., 2004). Since certain land use activities may pose a high risk, due to causing faecal pollution, an initial land-use survey of the catchment should be undertaken to: identify existing and planned developments, potential continuous, intermittent or seasonal pollution patterns and geological features likely to affect water quality and any existing or abandoned waste-disposal sites (NHMRC, 2004).

\section{Application}

The activities around the catchment and the source water were assessed following the steps in Fig. 4. The rivers that 


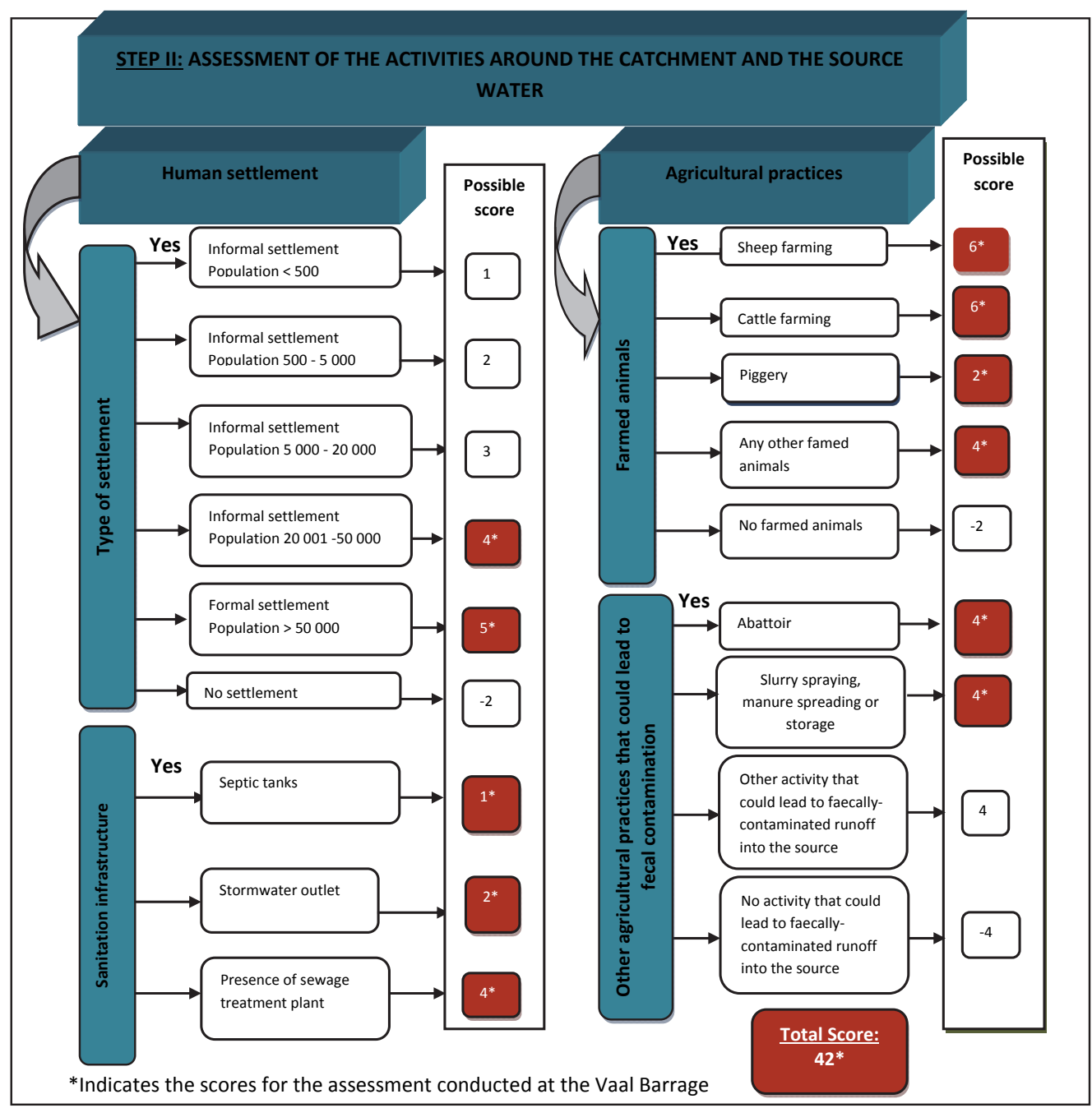

Figure 4

Assessment of the activities around the catchment and source water (adapted from NIEHS, 2002)

feed into the Vaal River Barrage Reservoir catchment include Suikerbosrand River, Klip River, and Rietspruit (Fig. 5). Visual assessment on land use and activities in the catchment was done and livestock farming, dryland farming, irrigation, mining, industrial activities and urban development were observed. Similar land use patterns were reported by Van Baalen (2003) and Osche (2007).

The increase in urban population, informal settlements, wastewater treatment plants and industrial complexes in the Vaal River Barrage catchment may have an impact on the rivers discharging into the Vaal River Barrage. A third of the Rietspruit catchment area is covered by informal settlements, urban areas, wastewater treatment plants, industry and mining (Van Baalen, 2003). Some of the formal and informal settlements in the catchments of the rivers feeding into the Vaal barrage do not have proper sanitation facilities.

Septic tanks and stormwater outlets are also present, increasing the risk of discharging faecally-contaminated water into the source water. The discharge of partially-treated wastewater may result in high concentrations of faecal micro-organisms of

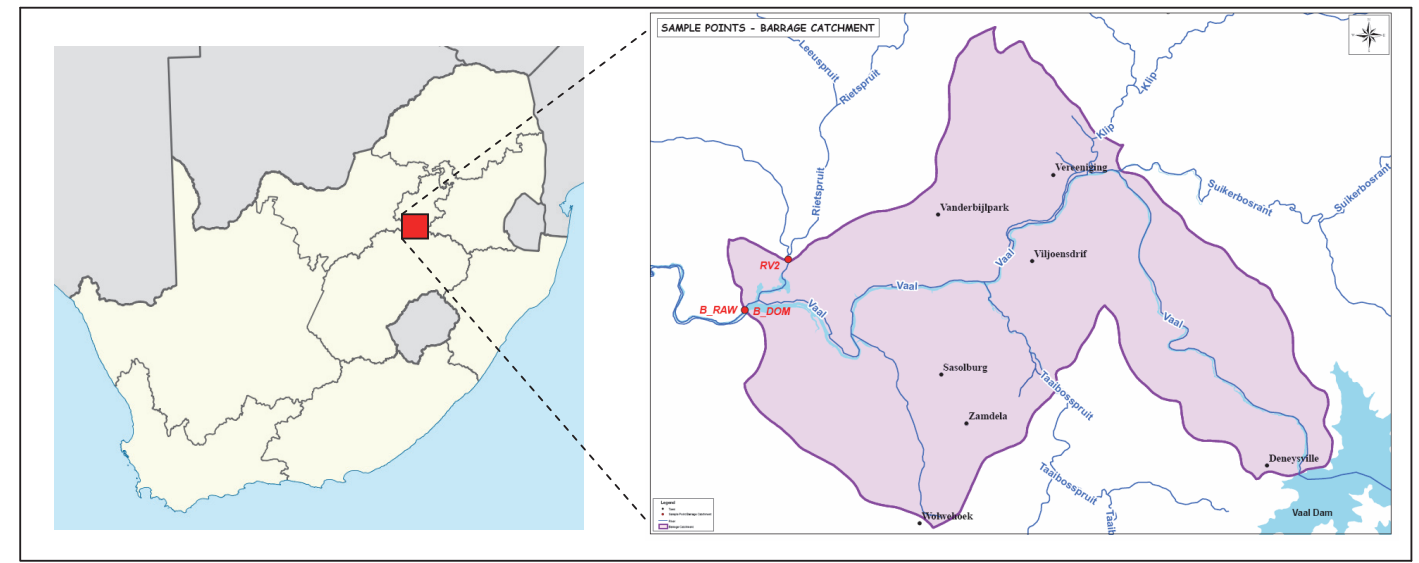

Figure 5

Sampling points used for the study (From: RW, 2007) 


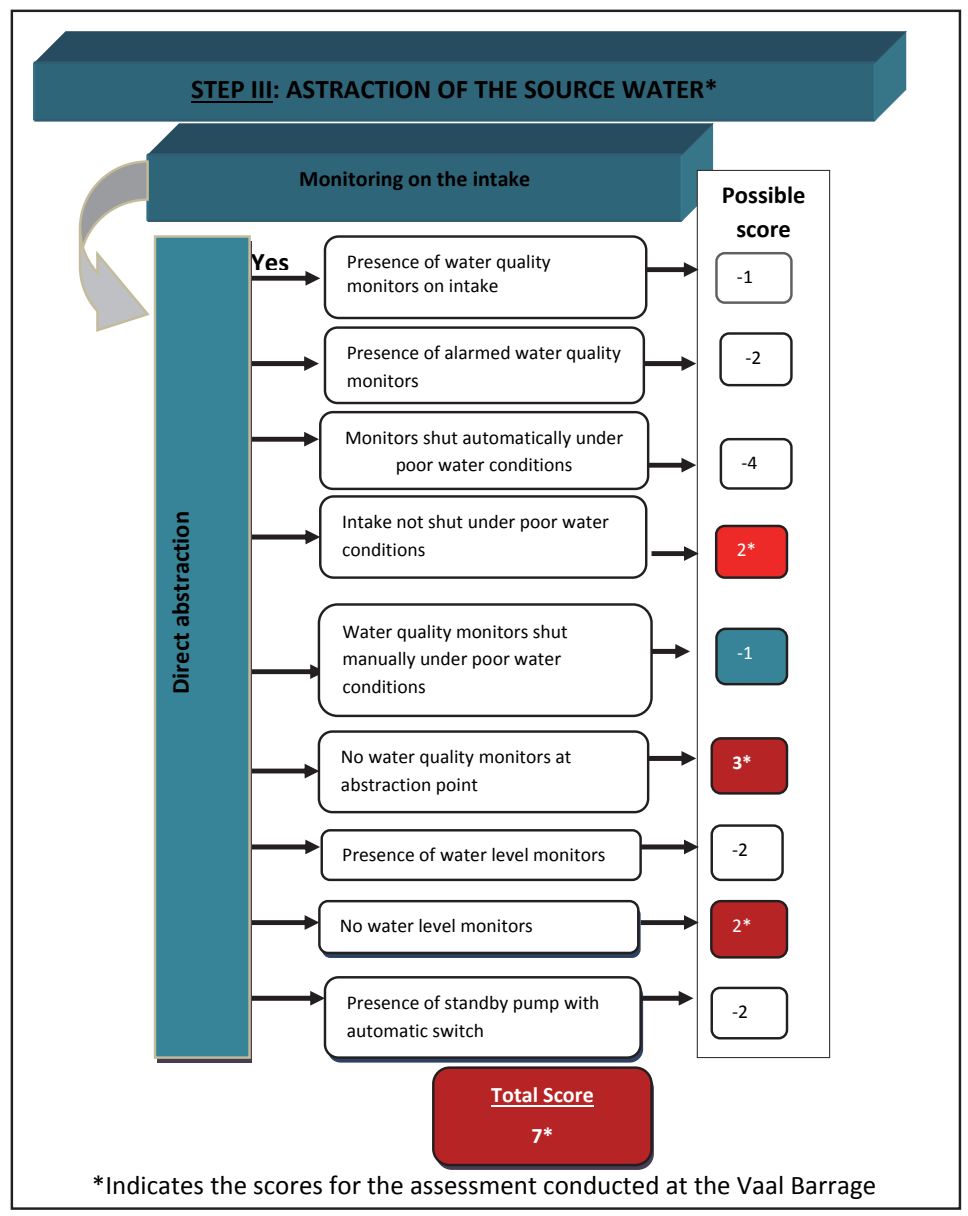

Figure 6

Monitoring at the abstraction point concern, such as E. coli, Klebsiella and parasitic protozoans such as Cryptosporidium and Giardia in the source water (Pitt, 2007). This is confirmed by Dungeni and Momba (2010), who reported that up to 400 Cryptosporidium oocysts/10 $\ell$ and up to 1750 Giardia cysts/ $10 \ell$ were detected in the effluents of some of the wastewater treatment plants in Gauteng.

Several events that could lead to increased faecal pollution on the Vaal River catchment have been reported. These include pumping of raw sewage into the Vaal River Barrage (FSE, 2009) and frequent overloading of the sewage works as a result of heavy rains, which results in spillage of the effluent into the Vaal River Barrage catchment (MG, 2006). These events could pose a serious health risk since untreated sewage samples have been found to contain an average of $1000-44$ 5000 Cryptosporidium oocysts/10 $\ell$ and $1000-513330$ Giardia cysts/10 $\ell$ (Robertson et al., 2006).

Source water monitoring activities also revealed that some of the rivers, such as the Rietspruit, Klip River and Suikerbosrand River (Fig. 5), contain high concentrations of faecal coliforms as well as a significant number of $E$. coli. For example, for the period January 2007 to January 2010 the average number of faecal coliforms in the Rietspruit, Klip River and Suikerbosrand River was 155409 (cfu/100 ml), 3792 (cfu/100 $\mathrm{m} \ell$ ) and $970(\mathrm{cfu} / 100 \mathrm{~m} \ell)$, respectively. From February 2010 to January 2013 the average number of E. coli in the Rietspruit Klip River and Suikerbosrand River was 8235 (MPN/100 ml), $5134(\mathrm{MPN} / 100 \mathrm{ml})$ and $805(\mathrm{MPN} / 100 \mathrm{ml})$, respectively. At the point of source water abstraction for the Vaal River Barrage drinking water purification plant the average number of faecal coliforms was $85 \mathrm{cfu} / 100 \mathrm{m \ell}$ from January 2007 to January
2010 and the average number of $E$. coli was $463 \mathrm{MPN} / 100 \mathrm{ml}$ ) from February 2010 to January 2013.

The presence of sheep farming, cattle farming and piggeries was observed at households in the catchment. The presence of even small farmed animals in the catchment could pose a risk since infected lambs, calves and goat kids have been reported to shed a significant number of cysts and oocysts between the ages of 5 and 25 days (Sari et al., 2009). Additionally, the piggeries (at Groenpunt Prison) discharging waste near the inlet of the Vaal river Barrage reservoir also pose a risk. Intensive stock farming (Karen Beef) was observed, which included an abattoir producing wastewater draining into the Suikerbosrand River.

\section{Step III: Abstraction of the source water (Fig. 6)}

This step allows for evaluation of the risk associated with the quality of water at the abstraction point. The quality of the water at the intake determines the ability of the treatment plant to effectively treat the water, which could pose a health risk. Monitoring at the abstraction point will assist in establishing the levels of source water contamination that can be handled. Monitoring at this point can also identify mechanical failures during abstraction as well as incidences such as power failures, which can assist in avoiding sourcing too little water from the intake to meet the demand (NZ Ministry of Health, 2001).

\section{Application}

During the assessment it was observed that the abstraction point at the Vaal Barrage catchment lacked online water quality 


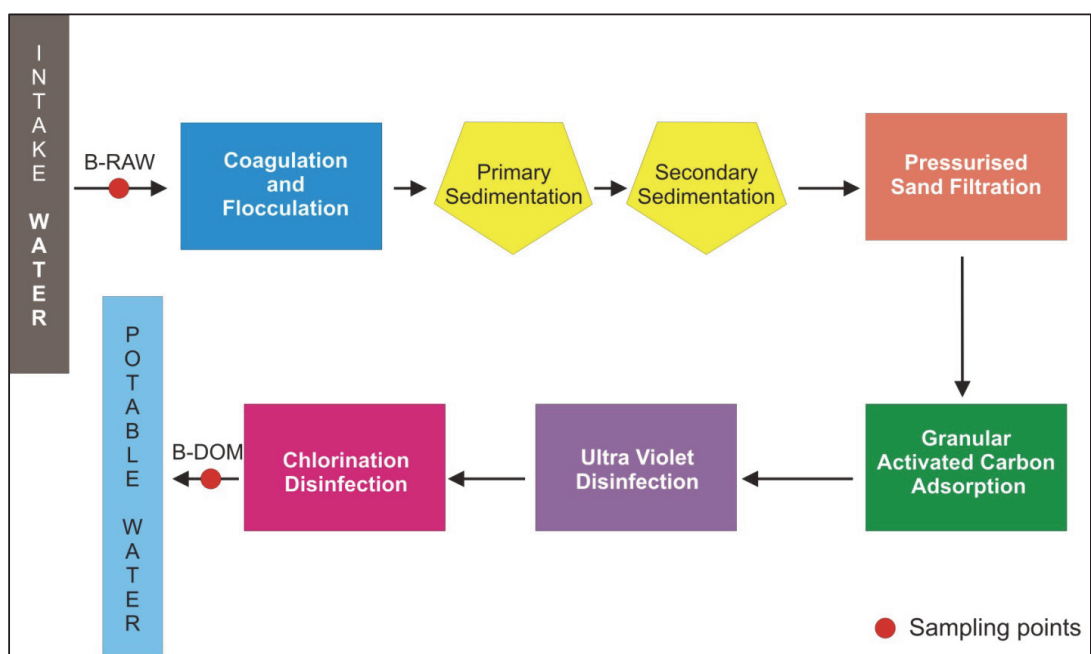

\section{Figure 7 \\ Schematic representation of the Vaal River Barrage water purification plant (Adapted from RW, 2009a)}

monitors, water level monitors or the additional stand-by pump, increasing the risk of overloading the water treatment system with water of poor quality. The results of the assessment are indicated in Fig. 6 .

\section{Step IV: Assessment of the water treatment plant (Fig. 7)}

It is critical to monitor the performance of the water treatment plant since it plays a significant role in ensuring that water from the catchment is treated in order for it to be safe for consumers to drink. For the water treatment plant to be completely effective in the removal of Cryptosporidium/Giardia from the source water the plant should be operating optimally with no interruptions.

Monitoring of plant performance includes assessing the situations in the plant that could lead to the breakthrough of Cryptosporidium and Giardia oocysts (NHMRC, 2004). The following areas of the water treatment plant are to be evaluated:

- The type of water treatment processes. Processes that should be evaluated include coagulation/flocculation, sedimentation, carbonation, filtration and disinfection (multibarrier approach). This approach has been reported to be effective for the removal of Cryptosporidium and Giardia oocysts. The use of disinfection only as well as the use of additional treatment (i.e. ozone treatment or UV treatment) will be evaluated (WHO, 2006)

- Operational parameters. Assessment of monitoring in the treatment plant will include monitoring of turbidity after coagulation, monitoring of residual coagulants, monitoring of floc settling rate, inspection of water clarity after sedimentation, as well as evaluation of $\mathrm{pH}$ during carbonation.

- Filter performance and turbidity during filtration. It is important to ensure that there are no disturbances in the flow and that the filter nozzles are in a good condition since this could result in poor particle removal (Haarolf, 2008). Monitoring of the turbidity resulting from each of the individual filters should be conducted to ensure that filtration is effective (NHMRC, 2004). For effective removal of Cryptosporidium oocysts and Giardia cysts it is important to maintain the turbidity at less than 0.5 NTU (NZ Department of Health, 2008).

- Quality control. This step will assist in evaluating the presence of a quality control system and the level of adherence thereto. For the treatment works to operate optimally it is important to ensure that all deviations to the quality control procedures are attended to. An example of the quality control systems that could be put in place for effective operation of the water purification plant are the ISO 9000 and ISO 14001.

\section{Application}

The Vaal River Barrage water purification plant uses coagulation/flocculation, sedimentation, carbonation, sand filtration, GAC treatment, UV irradiation and chlorination to treat source water (Fig. 7). A multi-barrier approach is used to achieve the water quality target in accordance with SANS 241-1 (2011). This approach is widely accepted for managing water quality and recommends the provision of water quality protection mechanisms at multiple points from the catchment to the tap (WHO, 2011). In addition a UV plant has been installed which in other studies has been reported to achieve up to $99 \%$ protozoan removal (WHO, 2006). Water flows through the UV plant where light intensity is maintained above $80 \%$; should it fall below this level there is an audible alarm. The water is tested on a grab sample basis. Should deterioration in quality of the UV output be noted by the operator, UV light tubes are replaced (RW, 2009a). Quality should meet the SANS Class 1 drinking water standard. A chlorination step follows UV treatment.

While assessing the operational parameters, it was observed that residual coagulant was not monitored, but other operational parameters such as floc settling rate, sedimentation and carbonation were closely monitored (Fig. 8). The filters were in good condition as there was no evidence of mud balls and algae (Fig. 9). No increase in the turbidity of the treated water was observed. Compliance levels of $99 \%$ were recorded during the evaluation period since it was less than $0.5 \mathrm{NTU}$ most of the time. During the period January 2007 to January 2013 the average NTU was 0.32 (Fig. 10)

Assessment of the quality control system indicated that a quality system was in place (the water treatment plant is ISO 9000 accredited); hence operational manuals are available, equipment is verified, operators are trained and deviations to quality are corrected by implementing the corrective actions (Fig. 11).

\section{Step V: Water quality monitoring (Fig. 12)}

In this step the availability of monitoring data for Cryptosporidium and Giardia is assessed. The availability of 


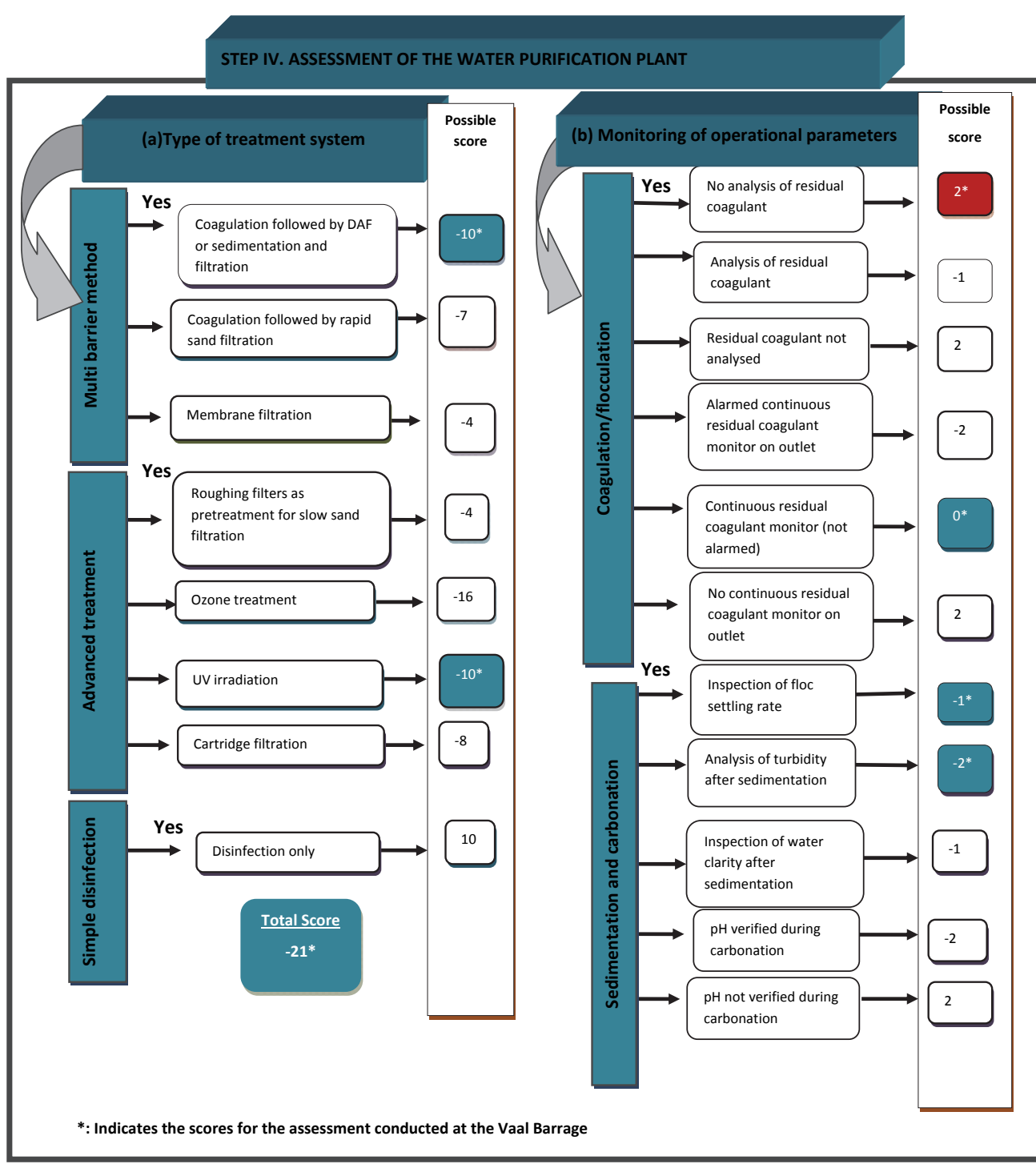

Figure 8

Assessment of the treatment system and operational parameters of the water purification plant

monitoring data will give an indication of the status of the source water in terms of risk. Hence it will assist the water utility in taking the necessary precautionary measures such as selecting the treatment method to be used, and developing an applicable sampling programme before using the source water. The data for treated water can also assist the water utility in evaluating whether the treatment process in place is effective or not. This can assist in identifying if there is a need to improve the treatment process or the monitoring processes to improve the mitigation of Cryptosporidium and Giardia (NHMRC, 2004). In South Africa the thresholds for Cryptosporidium and Giardia are less than 1 oocyst per $10 \ell$; in countries such as the UK, USA and Northern Ireland the minimum acceptable concentration for Cryptosporidium and Giardia is also less than 1 oocyst per $10 \ell$.

\section{Application}

It was found that both source water quality at the point of abstraction and treated water quality are monitored for Cryptosporidium and Giardia. Source water is monitored every second week whereas treated water is monitored every week.

For the purpose of this study, Cryptosporidium and Giardia data collected from January 2007 up to January 2013 were used and the following sampling points were used (Fig. 5):

- C-RV2: Sample point at the Rietspruit weir

- B-Raw: Source water at the point of abstraction

- B-Dom: Drinking water supply from the BDWPP

- Klip River

- Suikerbosrand River

The data indicated that water in Vaal River Barrage Reservoir contains Cryptosporidium and Giardia cysts. Source water monitoring results revealed that some of the rivers, such as the Rietspruit, Klip River and Suikerbosrand River, feeding into the Vaal River Barrage Reservoir and at the Vaal River Barrage intake (Figs 13 - 16) also contain high concentrations of Cryptosporidium and Giardia. For example, for the period January 2007 to January 2013 the average numbers of Cryptosporidium and Giardia in the Rietspruit (Table 1) were 295 oocysts/ $10 \ell$ and 153 cysts/10 $\ell$ respectively, in the Klip River were 31 oocysts $/ 10 \ell$ and 50 cysts $/ 10 \ell$, respectively, and in the Suikerbosrand River were 2 oocysts/10 $\ell$ and 1 cyst/10 $\ell$ respectively. A significant increase in Cryptosporidium concentrations was observed during February2010 and June 2010. This could most likely be as a result of wastewater discharges into the Rietspruit.

Although data obtained showed the presence of 


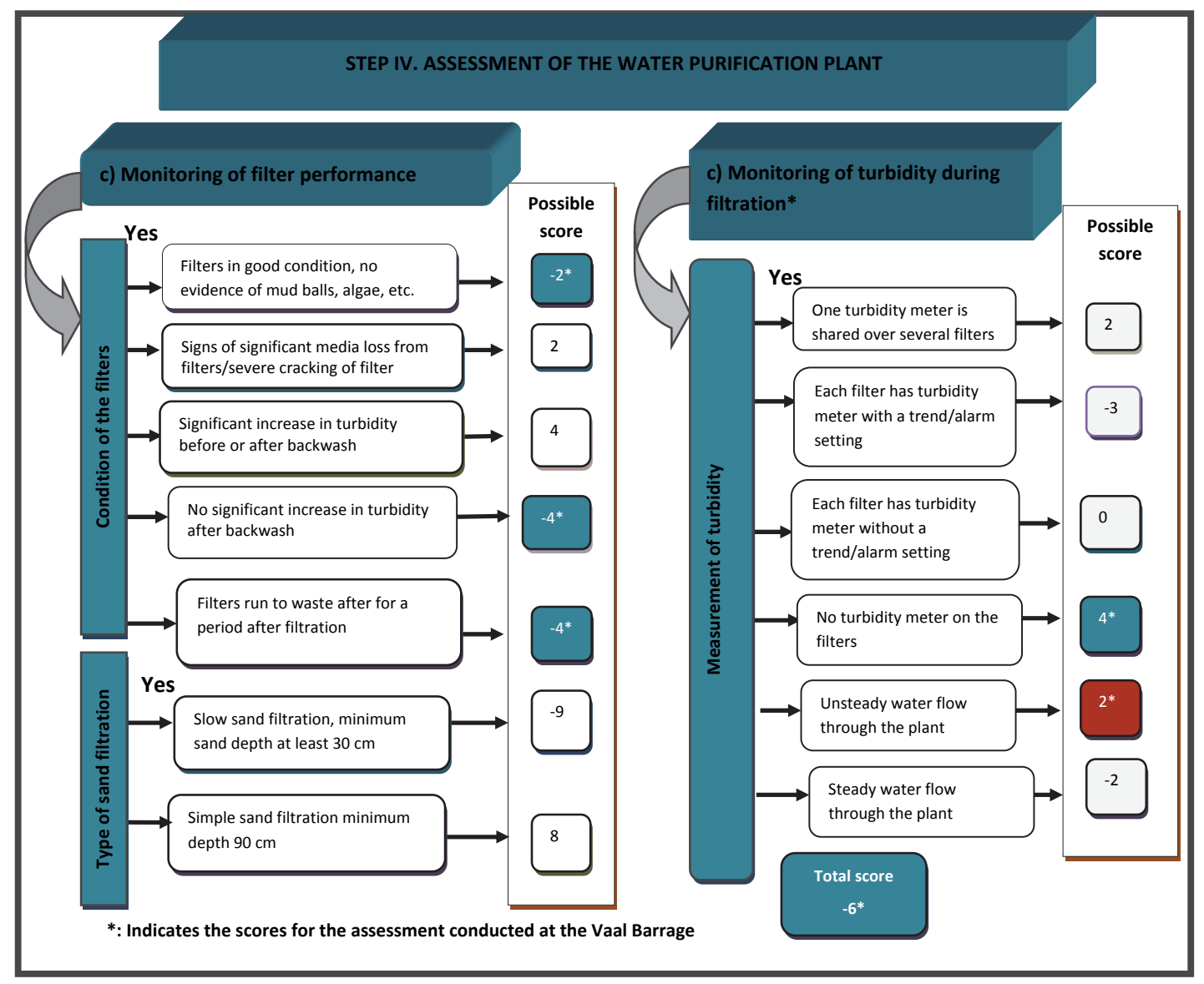

Figure 9

Assessment of the filter performance and turbidity during filtration

Cryptosporidium and Giardia cysts in the source water and the abstraction point (Fig. 16), only one Cryptosporidium oocyst was detected in the treated water and no Giardia cysts were detected in the treated water for the period January 2007 January 2013 (Table 1). This could be attributed to the multibarrier treatment system at the Vaal River Barrage drinking

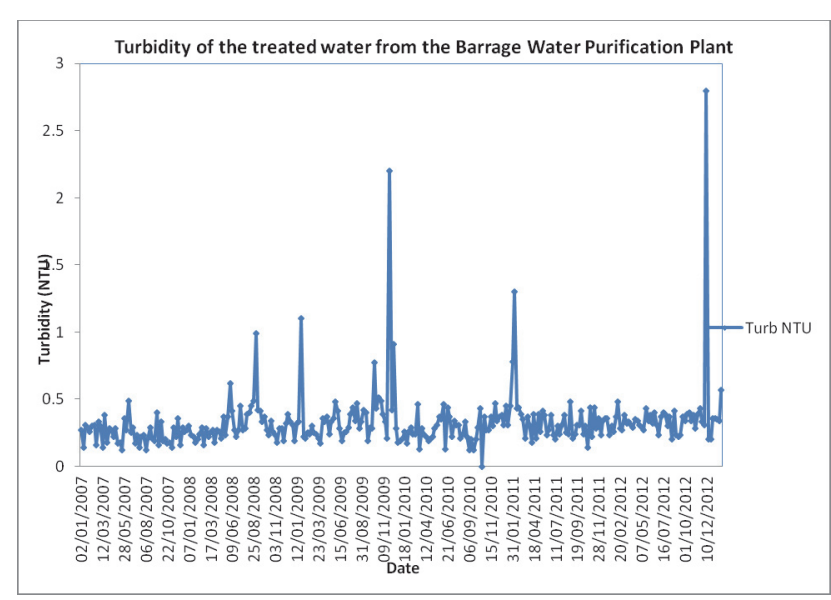

Figure 10 (above)

Turbidity of the treated water from Barrage water purification plant from January 2007 to December 2012

\section{Figure 11 (right)}

Steps involved during assessment of the presence of the quality control system

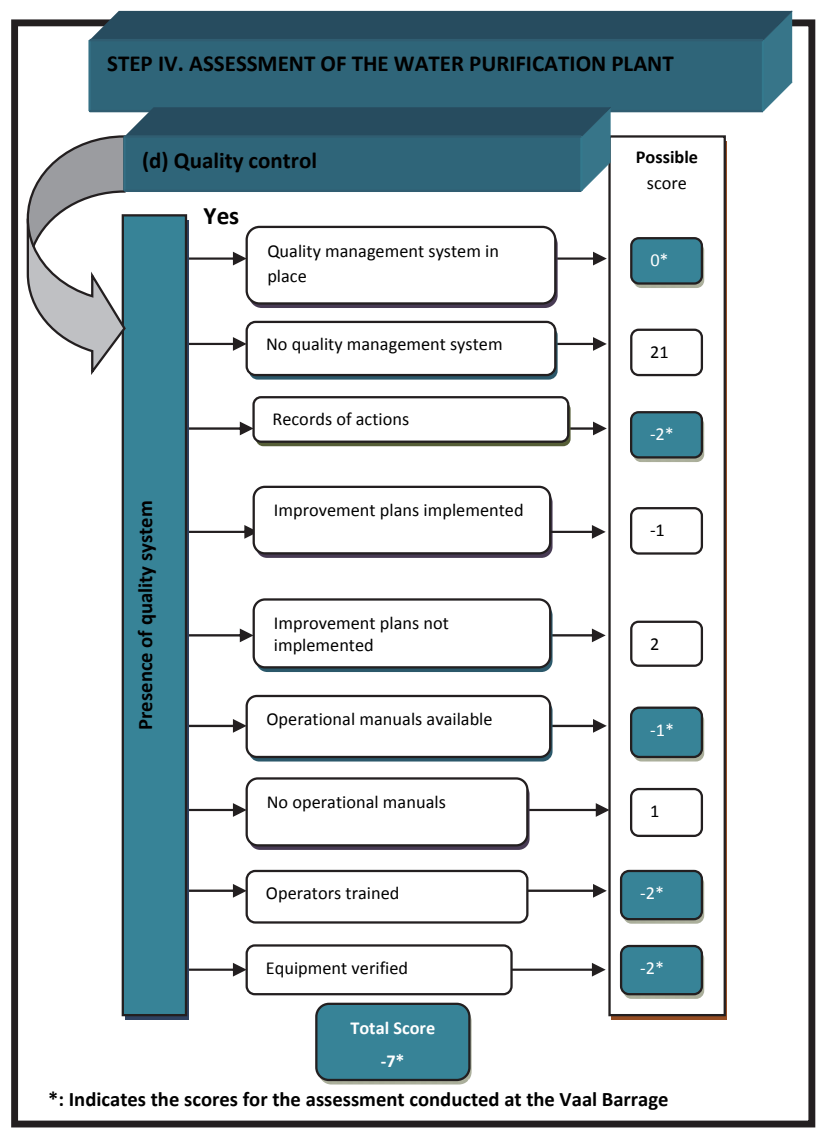




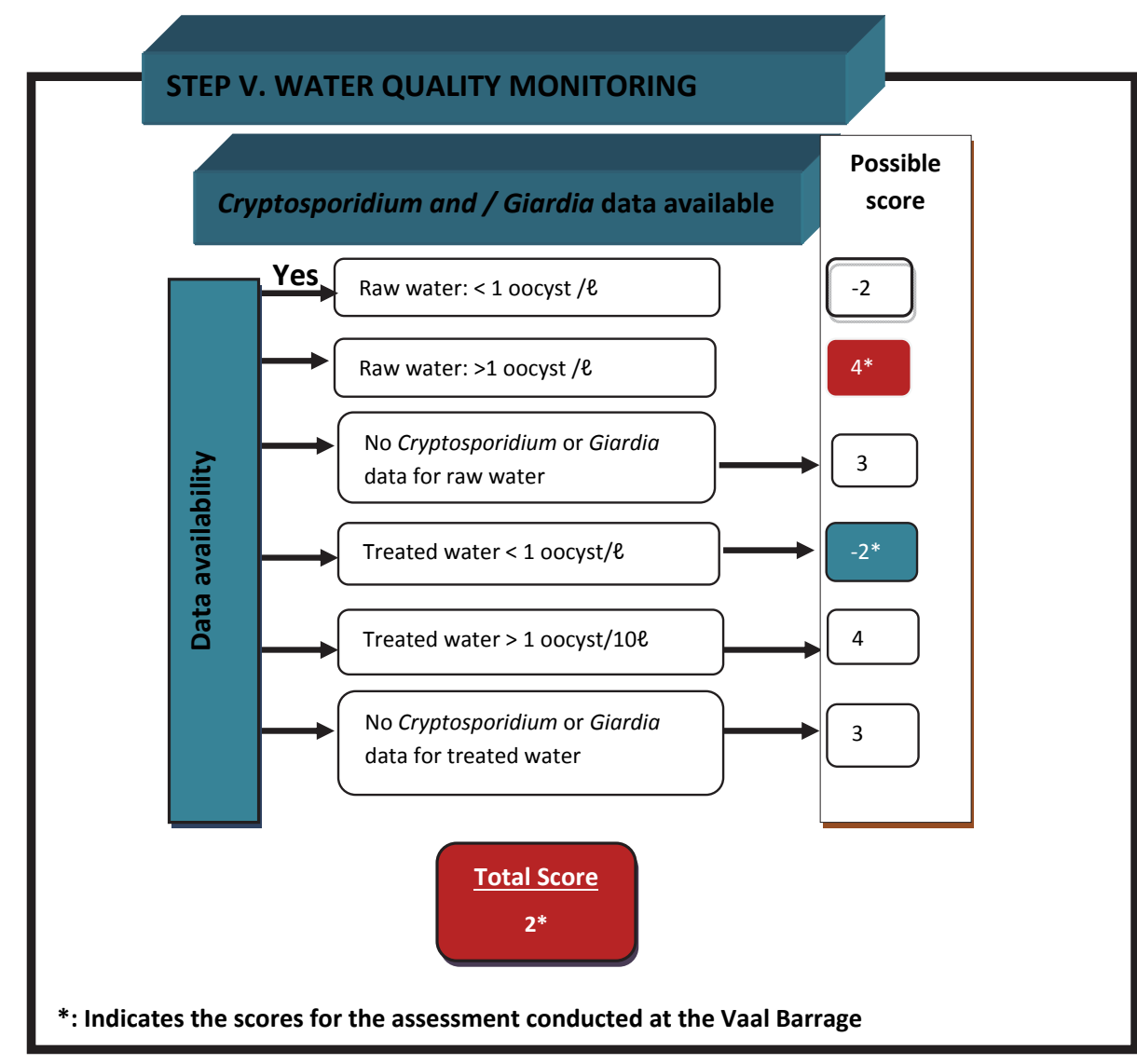

Figure 12 Activities involved during water quality monitoring

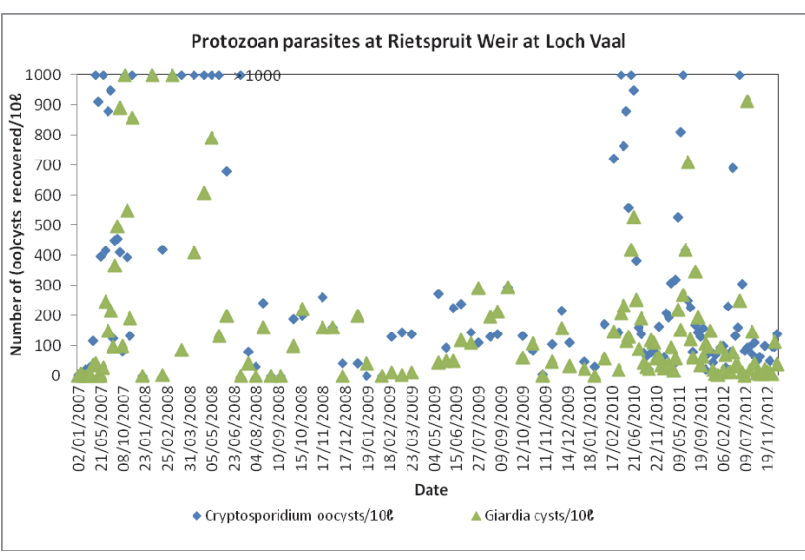

Figure 13

Cryptosporidium and Giardia ((oo)cysts/10 e) at Rietspruit Loch Vaal from January 2007 to January 2013

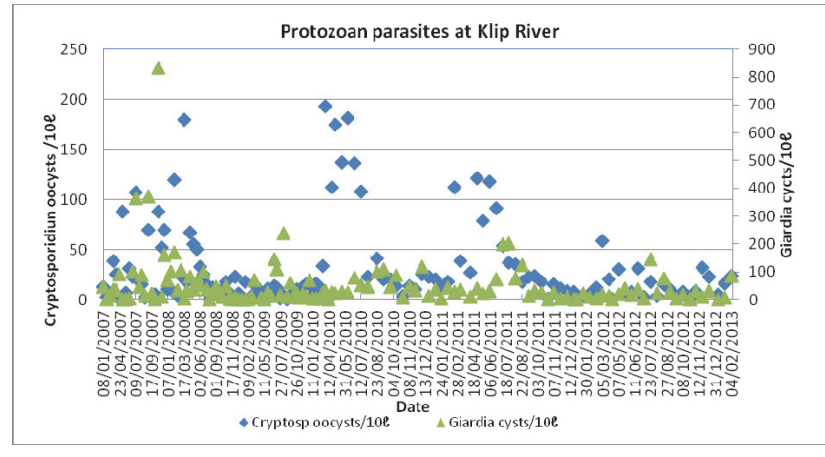

Figure 14

Protozoan parasites, Cryptosporidium and Giardia ((oo)cysts/10 ८) at the Klip River from January 2007 to January 2013

\begin{tabular}{|c|c|c|c|c|c|c|}
\hline \multicolumn{7}{|c|}{$\begin{array}{l}\text { TABLE } 1 \\
\text { The range, mean and standard deviation of Cryptosporidium (Crypto) and Giardia oocysts in the tributaries, abstraction } \\
\text { point and the final treated water }\end{array}$} \\
\hline \multirow[t]{2}{*}{ Sample } & \multicolumn{2}{|c|}{ Maximum (C/G per $10 \ell)$} & \multicolumn{2}{|c|}{ Average } & \multicolumn{2}{|c|}{ Standard deviation $\Sigma \sigma$} \\
\hline & Cryptosporidium & Giardia & Cryptosporidium & Giardia & Cryptosporidium & Giardia \\
\hline Rietspruit & $>1000$ & $>1000$ & 295 & 153 & 337 & 227 \\
\hline Klip River & 193 & 832 & 31 & 50 & 41 & 91 \\
\hline Suikerbosrand River & 36 & 44 & 2 & 1 & 5 & 5 \\
\hline Abstraction point & 20 & 43 & 0.6 & 0.66 & 2 & 4. \\
\hline Treated water & 1 & 0 & 0 & 0 & 0 & 0 \\
\hline
\end{tabular}




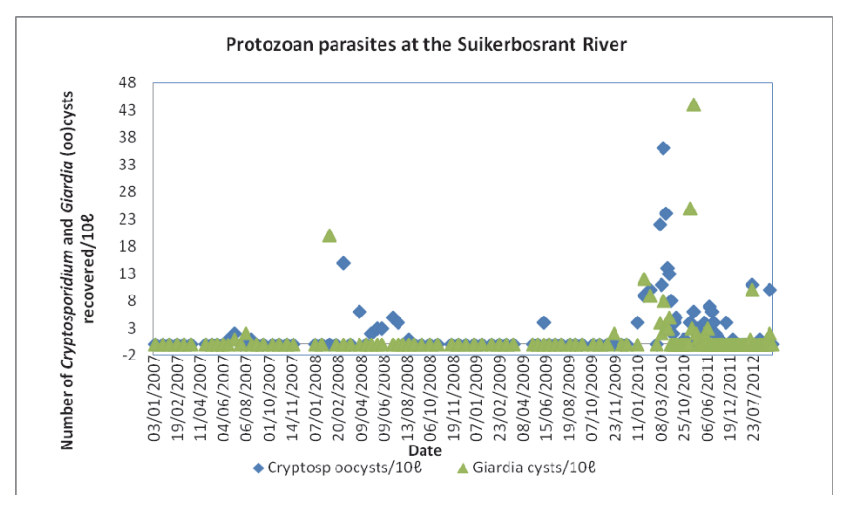

Figure 15

Protozoan parasites, Cryptosporidium and Giardia ((0o)cysts/10e) at the Suikerbosrand River from January 2007 to January 2013

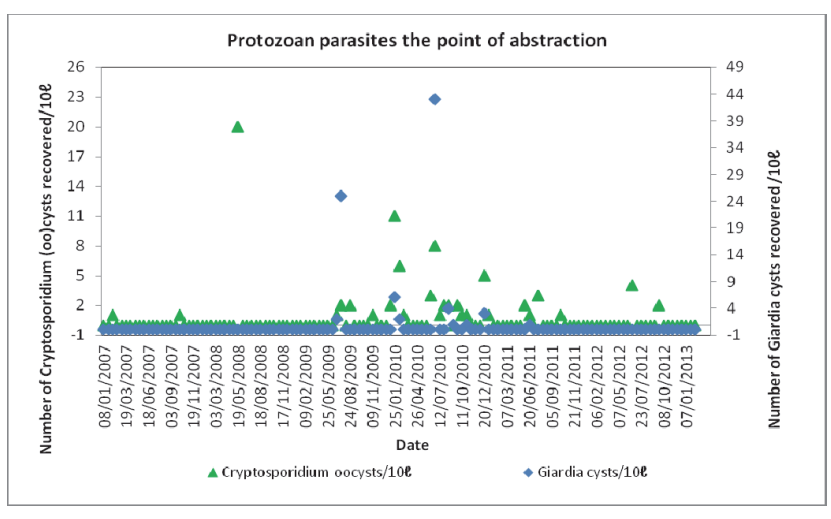

Figure 16

Protozoan parasites, Cryptosporidium and Giardia ((oo)cysts/10 e) at the abstraction point of the Barrage water purification plant from January 2007 to January 2013

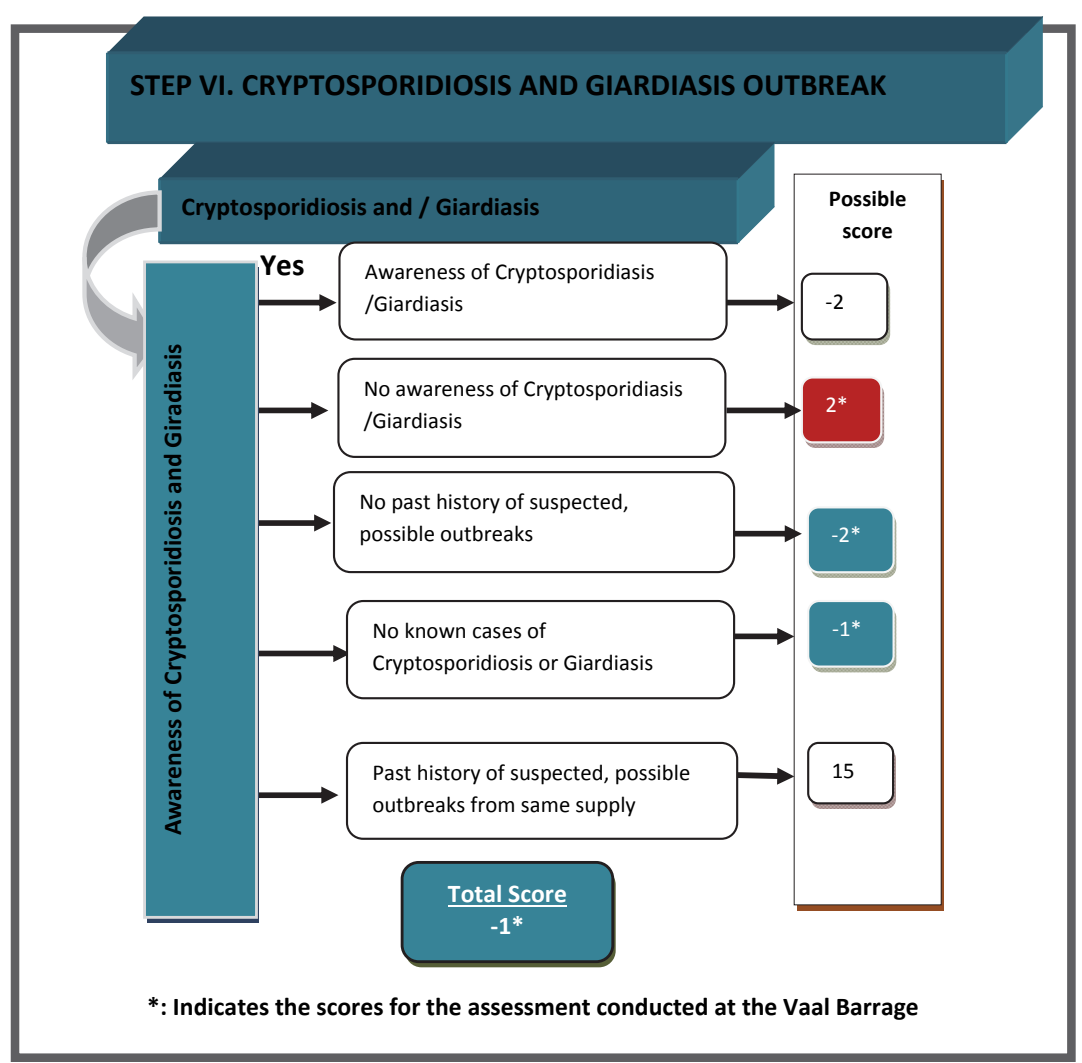

Figure 17

Cryptosporidiosis and

giardiasis outbreak (adapted from NI EHS, 2002) water purification plant as well as the presence of the advanced treatment system (the UV plant installed).

\section{Step VI: Cryptosporidiosis and giardiasis outbreak}

This step evaluates if there are any known incidences of cryptosporidiosis and/or giardiasis, whether cryptosporidiosis and/or giardiasis has been suspected and also checks awareness of the disease.

\section{Application}

The awareness of cryptosporidiosis and giardiasis was evaluated (Fig. 17), and the history of cryptosporidiosis and giardiasis from the same supply was evaluated. Results obtained indicated that there was lack of Cryptosporidium and Giardia awareness among the community. Therefore, no cryptosporidiosis and giardiasis has been reported at the Vaal River Barrage. In general there is a lack of cryptosporidiosis and giardiasis epidemiological data in South Africa.

\section{Step VII: Risk categorisation (Fig. 18)}

In this step all the scores assigned in the previous steps are processed in order to allocate the final risk score and rating. The proposed protocol will allow for assessment of a possible risk score from the source water as well as the possible risk of Cryptosporidium and Giardia that could arise from the water treatment plant.

Calculation of the final risk score is done according to 


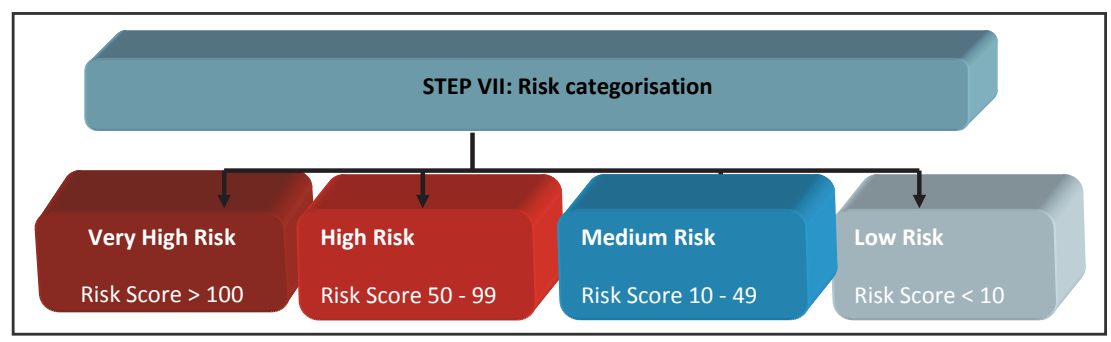

Figure 18

Characterisation of risk using the risk assessment scores the formula described in the guidelines for monitoring of Cryptosporidium in Northern Ireland (NI EHS, 2002) which is as follows:

Population Weighting $=0.4 \times \log 10$ (population served by supply)

Final Risk Assessment Score $=$ sum of total scores $\mathrm{x}$ population weighting $=?$

Risk is classified into 4 categories which are: very high risk (risk score $>100$; high risk $(50<$ score $<100)$; medium risk $(10<$ score $<50)$ and low risk (score < 10) (NI EHS, 2002).

\section{Application}

The risk score of the source water was calculated as follows: Based on the 2007 census figures which gave the population of the Vaal Triangle as 800819 (Statistics South Africa, 2007) and a $2 \%$ annual population growth rate (Emfuleni, 2008), the population of the Vaal Triangle in 2012 was estimated to be 880901.

\section{For this assessment:}

Population impacting the source water $=880901$

Population weighting $=0.4 \log _{10}(880901)=2.778$

Final risk score for source water:

$=$ sum of total score (source water) $\mathrm{x}$ population weighting $=(22+42) \times 2.778=177.79$

The risk score for the source water from the Vaal River Barrage Reservoir is 177.79, which implies that the Vaal River Barrage catchment can be regarded as a very high risk area for Cryptosporidium and Giardia.

The risk score for the treated water was calculated as follows:

\section{For this assessment:}

Population served by source $=450$

Population weighting $=0.4 \log _{10}(450)=1.06$

Final risk score for treated water:

= sum of total score (treated water) $\mathrm{x}$ population

weighting

$=[7+(-21)+(-8)+(-7)+2+4] \times 1.06$

$=-23 \times 1.06=-24.41$

Risk score for the treated drinking water from the Vaal River Barrage Drinking water purification plant is -24.4 . This implies that the drinking water from Vaal River Barrage drinking water purification plant can be regarded as low risk with regards to Cryptosporidium and Giardia since 24.41 is less than 10. This could be attributed to the multi-barrier water treatment system as well as the UV irradiation plant operational at the Vaal River Barrage. UV irradiation has been reported to be effective for
Cryptosporidium and Giardia removal where removal rates of up to $99.9 \%$ Cryptosporidium and Giardia oocysts can be achieved (WHO, 2006).

\section{PHASE III: Sampling, analysis and review}

This phase of the protocol includes sample collection, analysis, data storage and review. This phase clearly describes what to monitor, where to monitor, when and how to monitor for Cryptosporidium and Giardia. At the end of this phase it will be possible to quantify the magnitude of Cryptosporidium and/or Giardia contamination from the water sources.

\section{Step VIII: Sampling and laboratory processing}

\section{Sampling}

Sample collection is guided by risk classification since sample frequency, sampling points and the number of samples to be collected is determined by the risk score (Fig. 19). The recommendations for sampling and monitoring are given in Table 2; however, in the incidences where Cryptosporidium is detected in the final water, sampling must be done in accordance with the Incident Management Protocol described by DWAF (2007), irrespective of the risk score, until there are no oocysts detected in the treated water. The DWAF Incident Management Protocol involves increasing the sampling frequency, and notification of the municipality, Department of Water Affairs and the Department of Health.

Although the risk determines the sampling point and the sampling frequency it is important that, before sampling, the sampling programme and requirements and the protocol are discussed with the laboratory that will be in charge of the analysis. A $10 \ell$ plastic carboy or container is recommended for sampling. To avoid cross contamination it is recommended that carboys used for collection of source water be dedicated to source water only and those for drinking water be specifically used for collection of drinking water only. For sampling of the surface water it is important to ensure that sediment is not introduced into the sample and this can be achieved by sampling using a $5 \ell$ beaker until the required volume has been sampled (RW, 2009b).

\section{Laboratory processing}

The selected laboratory must use internationally accepted methods for the analysis of Cryptosporidium and Giardia, and analysis should be performed by a laboratory which has been accredited under international standard ISO/IEC 17025 (ISO/IEC 2005). In South Africa, the South African National Accreditation System (SANAS) is the body responsible for accreditation of analytical laboratories (Du Preez, 2000). 


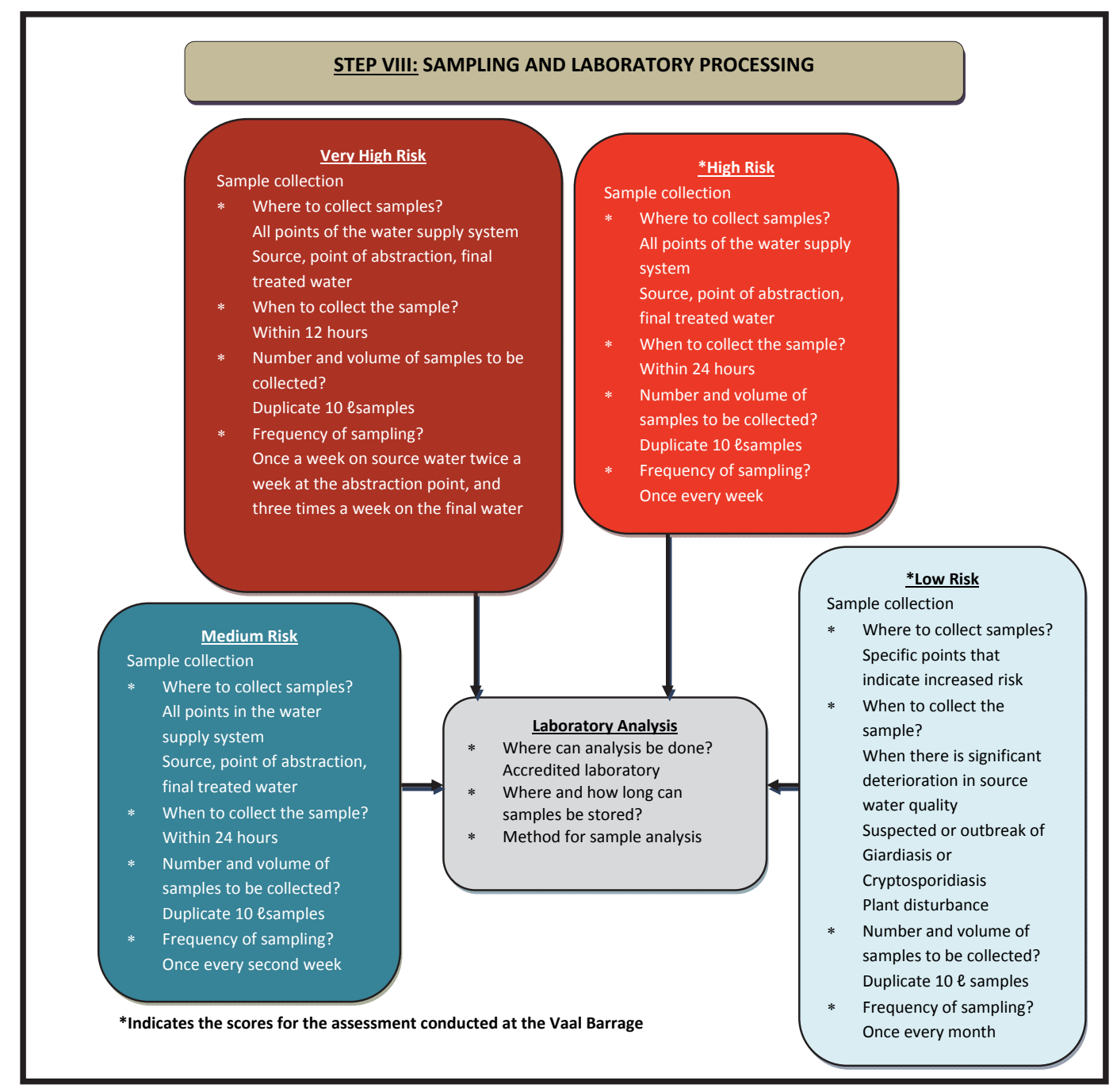

Figure 19

Activities involved during sampling and laboratory analysis

\section{Analytical methods}

At the laboratory samples could be stored for up to $96 \mathrm{~h}$ at $4^{\circ} \mathrm{C}$. There are a number of methods available for analysis of Cryptosporidium and Giardia. Methods such as sample concentration on flat membrane and cartridge filtration have been widely used and reviewed. However, due to the challenges associated with Cryptosporidium and Giardia analysis, it is recommended that the laboratory performing the analysis must have a documented quality control and quality system in place. It is recommended that published methods such as the US EPA Method 1623 (US EPA, 2005), Rand Water Method 06 (RW, 2010) and the DWI (2003) be followed for sample processing. Quality control procedures must be carefully followed and adhered to in order to render the results credible.

\section{Application}

The sample collection and analyses were conducted by Rand Water Analytical Services Laboratory which is accredited under International Standard ISO/IEC 17025 (ISO/IEC, 2005). A $10 \ell$ volume of water was collected in a carboy and transported to the laboratory. The sample was analysed using Rand Water Method 06 which involves sample filtration, elution, separation and staining. Quality was assured through reproducible calibration and testing of the filtration, immunomagnetic separation (IMS), staining, and microscopy systems (RW, 2010). Qualitative data analysis was performed by scanning each slide well for objects that meet the size, shape, and fluorescence characteristics of Cryptosporidium oocysts or Giardia cysts. Potential oocysts or cysts were confirmed through DAPI staining characteristics and DIC microscopy. Quantitative analysis was performed by counting the total number of objects on the slide confirmed as oocysts or cysts.

\section{Step IX: Data evaluation, interpretation and storage} (Fig. 20)

The results of the analysis were reported as oocysts or cysts per $10 \ell$. Reporting of non-compliant data must be done according to the available protocols. In South Africa, data is evaluated against the National Drinking Water Quality Standard (SANS 241-2011). Any incidence of Cryptosporidium or Giardia in treated water at a concentration of 1 or more oocysts in $10 \mathrm{l}$ is dealt with following the procedures described in the Protozoan Incident Management Framework of South Africa as set out in DWAF (2007).

All of the results should be stored in the database provided by the company. At Rand Water, for example, data is stored in the laboratory information management system (LIMS). Alternatively, data can be stored at the facilities of the governing authority. An example of such an authority in South Africa 


\begin{tabular}{|c|c|c|c|c|}
\hline \multicolumn{5}{|c|}{$\begin{array}{c}\text { TABLE } 2 \\
\text { Sampling and monitoring after risk categorization }\end{array}$} \\
\hline \multirow[t]{2}{*}{ Risk category } & \multicolumn{4}{|l|}{ Sample collection } \\
\hline & Where & When & Volume & Monitoring Frequency \\
\hline $\begin{array}{l}\text { Very High } \\
\text { Risk }\end{array}$ & $\begin{array}{l}\text { All points in the water sup- } \\
\text { ply system. } \\
\text { Source, point of abstrac- } \\
\text { tion, final treated water. }\end{array}$ & Within $24 \mathrm{~h}$ & $\begin{array}{l}\text { Duplicate } \\
10 \ell \text { samples }\end{array}$ & $\begin{array}{l}\text { Once a week on source water and after } \\
\text { filtration } \\
\text { Twice a week at the abstraction point } \\
\text { Three times a week on the final water }\end{array}$ \\
\hline High Risk & $\begin{array}{l}\text { All points of the water sup- } \\
\text { ply system. } \\
\text { Source, after filtration, } \\
\text { final treated water. }\end{array}$ & Within $24 \mathrm{~h}$ & $\begin{array}{l}\text { Duplicate } \\
10 \ell \text { samples }\end{array}$ & $\begin{array}{l}\text { Once a week until risk has been } \\
\text { reduced to medium risk }\end{array}$ \\
\hline $\begin{array}{l}\text { Medium } \\
\text { Risk }\end{array}$ & $\begin{array}{l}\text { All points in the water sup- } \\
\text { ply system. } \\
\text { Source, after filtration, } \\
\text { final treated water. }\end{array}$ & Within $24 \mathrm{~h}$ & $\begin{array}{l}\text { Duplicate } \\
10 \ell \text { samples }\end{array}$ & Once every second week \\
\hline Low Risk & $\begin{array}{l}\text { Specific points that indi- } \\
\text { cate increased risk. }\end{array}$ & $\begin{array}{l}\text { When there is significant dete- } \\
\text { rioration in source water quality } \\
\text { Suspected or outbreak of } \\
\text { Giardiasis or Cryptosporidiosis } \\
\text { Plant disturbance }\end{array}$ & \begin{tabular}{|l|} 
Duplicate \\
$10 \ell$ samples
\end{tabular} & Once a month \\
\hline
\end{tabular}

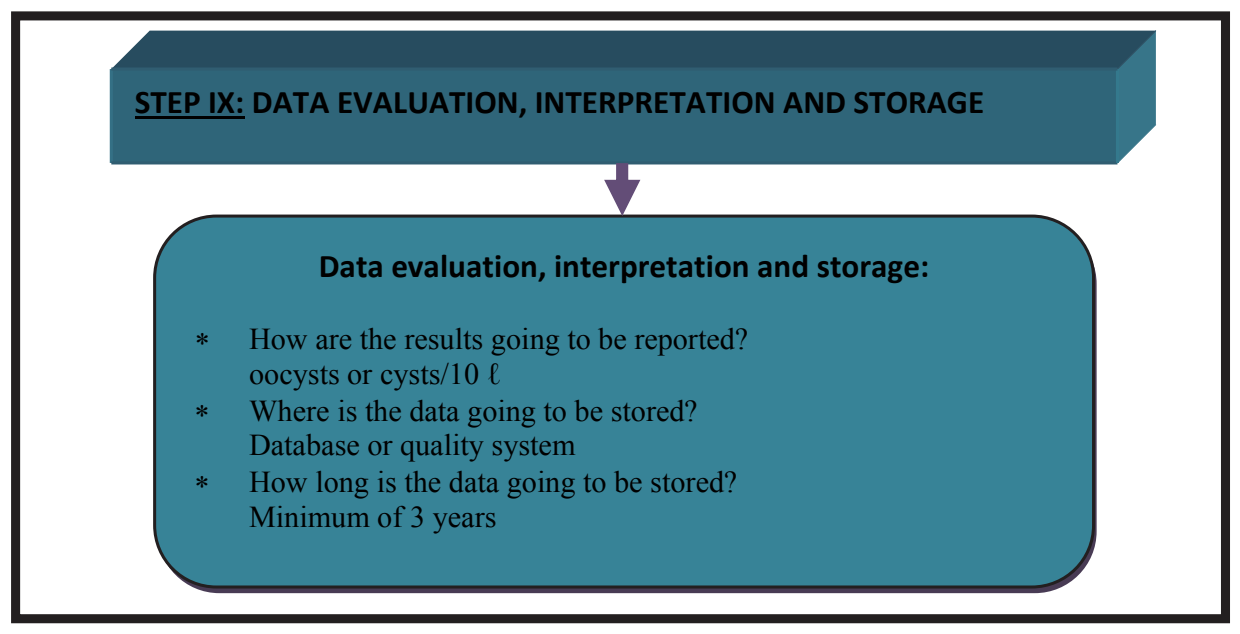

Figure 20

Data evaluation interpretation and storage is the Department of Water Affairs (DWA) which is the custodian of drinking water in South Africa. Furthermore data reports should be compiled and these should be stored for at least 3 years.

\section{Application}

The results of the analysis were reported as oocysts or cysts per $10 \ell$. The results were stored in the LIMS database. Data reports were compiled and these are stored for at least 3 years (RW, 2010). These are reported to DWA as a part of Blue Drop requirements.

\section{PHASE IV: Monitoring process review}

During this phase, the date of the next review will be determined.

\section{Step X: Process evaluation and review (Fig. 21)}

During the review the mitigation measures taken should be considered. These should be noted in the desktop survey. The review should take place every 3 years or if there is significant deterioration of the source water quality, a suspected cryptosporidiosis or giardiasis outbreak or in the event of plant disturbance which could possibly result in the leakage of Cryptosporidium and/or Giardia oocysts into the treated water (NI EHS, 2002). However, in the case of very high risk areas the frequency of monitoring could be increased and the mitigation measures be imposed until the results are satisfactory. An example of such measures is the analysis of water samples following the incident management protocol set out in DWAF (2007). The desktop survey should be re-assessed in order to ensure that there are no major changes in the regulations.

\section{Application}

Evaluation of the Vaal River Barrage catchment indicated that it is a very high risk area for Cryptosporidium and Giardia. Samples should be collected at the points of the water treatment system identified as very high risk. The sampling frequency for these areas should be once a week at the source water, twice a week at the abstraction point and 3 times a week on the final water until the risk has been reduced to 


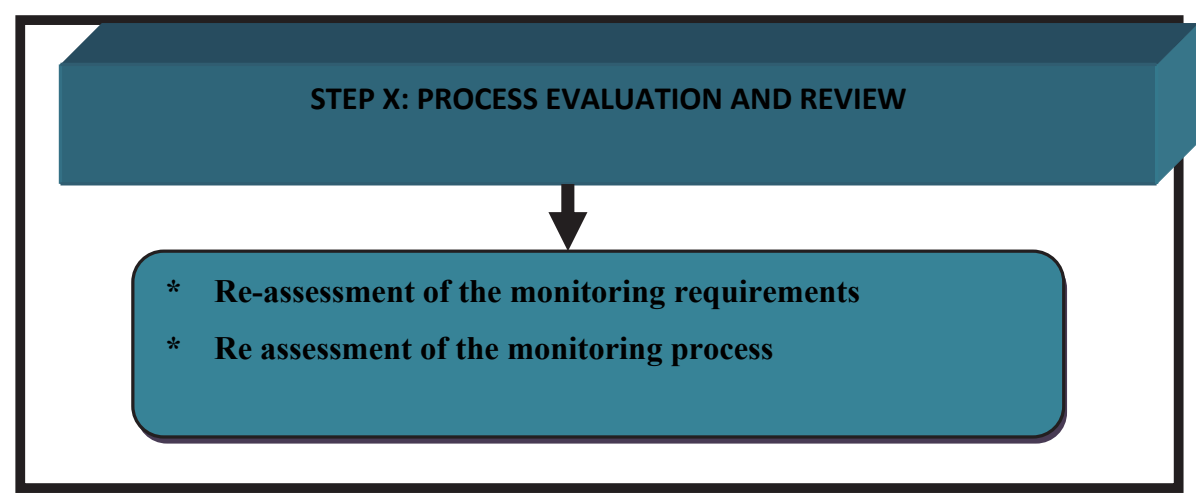

Figure 21

Process evaluation and review 'medium' or 'minimum'. However, if Cryptosporidium oocysts and/or Giardia cysts are found in drinking water samples, a corresponding sampling frequency should accordingly be adopted, as stipulated in the Protozoan Incident Management Framework. This involves increasing the sampling frequency, notification of the municipality, Department of Water Affairs and Department of Health (DWAF, 2007). In cases where there is an expansion in the water supply or the capacity of the water treatment plant is exceeded and if there are any operational changes in the plant, the entire water supply system will be evaluated for risk using this protocol.

During the review the mitigation measures taken should be considered and these should be noted in the desktop survey. The review will take place every 3 years or if there is significant deterioration of the raw water quality, if there is a suspected cryptosporidiosis or giardiasis outbreak or in the event of plant disturbance which could possibly result in the leakage of Cryptosporidium and/or Giardia oocysts into the treated water (NI EHS, 2002). However, in case of high risk areas the frequency of monitoring could be increased and the mitigation measures be imposed until the results are satisfactory.

\section{CONCLUSIONS}

The primary objective of the study was to develop a protocol/ methodology that can be applied by drinking water producers to monitor Cryptosporidium and Giardia. The developed protocol was applied at a drinking water plant receiving source water from the Vaal River Barrage reservoir. Applying the protocol showed that it was easy to follow and resulted in the identification of the risk areas and potential risks in the water supply system. The approach of developing a protocol and testing it under operational conditions appeared to be effective and should be followed in future studies. The only constraint is that the study was tested on one water treatment plant. From the study, it can be concluded that the source water from the Vaal River Barrage catchment was a very high risk. However, the use of the multibarrier approach coupled with advanced treatment using UV rendered the water almost free of Cryptosporidium and Giardia. Therefore, the population receiving treated water from the Barrage purification plant is not at risk of cryptosporidiosis and giardiasis.

Using the protocol could also benefit water utilities as it can assist managers to evaluate their source water catchments and establish the Cryptosporidium and Giardia risk status of the water resource. Improvement strategies, for example, negotiations with the local and national government to improve catchment management strategies, can thus be implemented. The water utility can decide to reduce the risk of Cryptosporidium and Giardia contamination by implementing advanced treatment processes or by upgrading their treatment processes, particularly through the addition of UV or ozone treatment. In addition, the protocol can be used by water utilities as part of their monitoring strategy as required in Water Safety Planning.

The approach can also be used by the catchment management agencies as one of the tools that will assist them in identifying the potential risks that could have an impact on the catchments. The developed protocol is thus beneficial to governmental agencies as well as water utilities tasked to ensure the production of safe drinking water for consumers.

\section{ACKNOWLEDGEMENTS}

The authors will like to thank Rand Water for technical and financial support, without which this study would not have been possible.

\section{REFERENCES}

BENTACOURT WQ and ROSE JB (2004) Drinking water treatment processes for removal of Cryptosporidium and Giardia. Vet. Parasitol. 126 219-234.

CACCIÒ M, THOMPSON RCA, MCLAUNCHLIN J and SMITH HV (2005) Unraveling Cryptosporidium and Giardia epidemiology. Trends in Parasitology 21 (9) 430-437.

CARMENA D (2010) Waterborne transmission of Cryptosporidium and Giardia: detection, surveillance and implications for public health. In: Méndez-Vilas A (ed.) Current Research, Technology and Education topics in Applied Microbiology and Microbial Biotechnology. 1-14.

CARMENA D, CARDONA GA and SÁNCHEZ-SERRATO LP (2012) Current situation of Giardia infection in Spain: implications for public health. World J. Clin. Infect. Dis. 2 (1) 1-12.

DUNGENI M and MOMBA MNB (2010) The abundance of Cryptosporidium and Giardia spp. in treated effluents produced by four wastewater treatment plants in the Gauteng Province of South Africa. Water SA 36 (4) 425-432.

DU PREEZ HH, HEATH RGM, SANDHAM LA and GENTHE B (2003) Methodology for the assessment of human health risks associated with consumption of chemical contaminated freshwater fish in South Africa. Water SA 29 (1) 69-90.

DWAF (DEPARTMENT OF WATER AFFAIRS AND FORESTRY, SOUTH AFRICA) (2004) National Microbial Water Quality Monitoring Programme. DWAF, Pretoria.

DWAF (DEPARTMENT OF WATER AFFAIRS AND FORESTRY, SOUTH AFRICA) (2007) Drinking Water Quality Framework for South Africa. DWAF, Pretoria.

DWI (DRINKING WATER INSPECTORATE) (2003) Standard operating protocol for the monitoring of Cryptosporidium oocysts in treated water supplies to satisfy the Water Supply (Water Quality) Regulations 2000, SI No 3184, England, Water Supply (Water 
Quality) Regulations 2001, SI No 3911 (W.323), Wales. Drinking Water Inspectorate, London.

DWI (DRINKING WATER INSPECTORATE) (2008) Guidance on the Water Supply (Water Quality) Regulations 2000 (England) incorporating the Water Supply (Water Quality) Regulations 2000 (Amendment) Regulations 2007 and the Water Supply (Water Quality) Regulations 2001 (Wales) incorporating the Water Supply (Water Quality) Regulations 2001 (Amendment) Regulations 2007. ( $3^{\text {rd }}$ edn.) Drinking Water Inspectorate, London.

EMFULENI (2008) Emfuleni Local Municipality Annual Report 2007/8. URL: http://www.emfuleni.gov.za/docs/annual/0708/ annual report.pdf (Accessed 05 March 2013).

NI (NORTHERN IRELAND) EHS (ENVIRONMENT AND HEALTH SERVICE) (2002) Guidance for the monitoring of Cryptosporidium treated water supplies in Northern Ireland. Environment and Health Service, Northern Ireland Department of Environment, Belfast.

ESSF (EARTH SCIENCES FOR SOCIETY FOUNDATION) (2005). Groundwater - catchment for a thirsty planet? URL: http: www. yearofplanetearth.org/content/.../Groundwater.pdf (Accessed 5 October 2010).

FSE (FEDERATION FOR SUSTAINABLE ENVIRONMENT) (2009) Disaster at Vaal River caused by Emfuleni officials. URL: http:// www.fse.org.za (Accessed 20 October 2010).

HEALTH CANADA (2008) Guidelines for Canadian Drinking Water Quality. Summary Table. Health Canada, Ontario. 14 pp.

ISO/IEC (INTERNATIONAL STANDARDS ORGANIZATION/ INTERNATIONAL ELECTROTECHNICAL COMMISSION) (2005) General requirement for the competence of calibration and testing laboratories. ISO/IEC 17025:2005. ISO, Geneva.

MG (MAIL AND GUARDIAN) 2006. Sewage disaster hits Vaal River ecosystem. URL: http://www.mg.co.za/article/2006-01-17-sewagedisaster-hits-vaal-river-ecosystem (Accessed 19 October 2010).

MURRAY K, DU PREEZ M, KUHN AL and VAN NIEKERK H (2004) A pilot study to demonstrate implementation of the national microbial monitoring programme. WRC Report No. 1118/1/04. Water Research Commission, Pretoria. 130 pp.

NHMRC (NATIONAL HEALTH AND MEDICAL RESOURCE COUNCIL, AUSTRALIA) (2004) Australian Drinking Water Guidelines. National Health and Medical Resource Council, Australia.

NI (NORTHERN IRELAND) DEPARTMENT FOR REGIONAL DEVELOPMENT (2007) Water Supply Water Quality Regulations Northern Ireland. Statutory rules of Northern Ireland No. 147 Water and Sewerage. Northern Ireland Department for Regional Development, Belfast.

NZ (NEW ZEALAND) MINISTRY OF HEALTH (2001) Surface water abstraction - rivers, streams and infiltration galleries. Public Health Risk Management Plan. New Zealand Ministry of Health. URL: http://www.moh.govt.nz (Accessed 1 October 2010).

NZ (NEW ZEALAND) MINISTRY OF HEALTH (2008) Drinking Water Standards for New Zealand. New Zealand Ministry of Health, Wellington.

OSCHE E (2007) Seasonal rainfall influences on main pollutants at the Vaal River Barrage Catchment: Temporal-spatial perspective. Masters dissertation, Rand Afrikaanse Universiteit, Johannesburg.
PITT R (2007) Micro-organisms in urban surface waters. URL: $\underline{\text { http:// }}$ unix.eng.ua.edu/ rpitt/Class/ExperimentalDesignFieldSampling/ MainEDFS.html (Accessed 10 October 2010).

RSA (REPUBLIC OF SOUTH AFRICA) (1998) Water Services Act No.108 of 1997. Republic of South Africa. Government Printer, Pretoria

RSA (REPUBLIC OF SOUTH AFRICA) (1998) National Water Act No.36 of 1998., Republic of South Africa. Government Printer, Pretoria

RW (RAND WATER) (2010). Isolation and detection of Cryptosporidium and Giardia Method No. 1.2.2.06.1. Rand Water Scientific Services. (Unpublished.)

RW (RAND WATER) (2009a) Management of water quality barrage treatment plant. Rand Water DOC. NO: BWD/LAB/00014/PR. Bulk water distribution. (Unpublished.)

RW (RAND WATER) (2009b) Sample collection, preservation and storage for transporting to laboratory. Rand Water Working Instruction No 1. 2. 1. 12. 1. Rand Water Scientific Services. (Unpublished.)

RW (RAND WATER) 2008. Water origination: Where does our water come from? URL: http://www.randwater.co.za/ CorporateResponsibility/WWE/Pages/WaterOrigination.aspx (Accessed 20 October 2010).

ROBERTSON LJ, HERMANSEN L and GJERDE BK (2006) Occurrence of Cryptosporidium oocysts and Giardia cysts. Appl. Environ. Microbiol. 72 (8) 5297-5303.

SANS (SOUTH AFRICAN NATIONAL STANDARDS) (2011) SANS 241-1. Drinking Water Quality. South African Bureau of Standards, Pretoria.

SARI B, ARSLAN MO, GICIK Y, KARA M and TAŞ CI (2009) The prevalence of Cryptosporidium species in diarrhoeic lambs in Kars province and potential risk factors. Trop. Anim. Health Prod. 41 819-826.

SMITH HV and ROSE JB (1998) Waterborne cryptosporidiosis: current status. Parasitol. Today 14 (1) 14-22.

STATISTICS SOUTH AFRICA (2007) Statistics South Africa. Basic results municipalities. Community Survey. Statistical Release P0301.1. URL: http://www.statssa.gov.za/publications/p03011/ p030112007.pdf (Accessed 5 March 2013).

US EPA (US ENVIRONMENTAL PROTECTION AGENCY) (2005) Method 1623: Cryptosporidium and Giardia in Water by Filtration/ IMS/FA. EPA 815-R-05-002. United States Environmental Protection Agency, Washington DC.

US EPA (UNITED STATES ENVIRONMENTAL PROTECTION AGENCY) (2006) Source Water Monitoring Guidance Manual for Public Water Systems for the Final Long Term 2 Enhanced Surface Water Treatment Rule. United States Environmental Protection Agency, Washington DC.

VAN BAALEN L (2003) Phytoplankton dynamics of the Loch Vaal - A eutrophied shallow lake in Gauteng. Masters dissertation, Potchefstroom University for Higher Christian Education, Potchefstroom.

WHO (WORLD HEALTH ORGANIZATION) (2006) Guidelines for drinking water quality. First addendum to third edition. Recommendations. ( $3^{\text {rd }}$ edn.). WHO, Geneva.

WORLD HEALTH ORGANIZATION (WHO) (2011) Guidelines for Drinking-Water Quality ( $4^{\text {th }}$ edn.). WHO, Geneva. 